\title{
Haemoptysis due to endobronchial telangiectasias
}

\author{
Saurabh Mittal, ${ }^{\oplus}$ Karan Madan, ${ }^{1}$ Anant Mohan, ${ }^{1}$ Tarun Krishna Boppana ${ }^{2}$
}

${ }^{1}$ Pulmonary, Critical care and Sleep Medicine, All India Institute of Medical Sciences New Delhi, India

${ }^{2}$ Rheumatology, All India Institute of Medical Sciences, New Delhi, India

\section{Correspondence to} Dr Saurabh Mittal, saurabh_kgmu@yahoo.co.in

Accepted 3 August 2019

Check for updates

(C) BMJ Publishing Group Limited 2019. No commercial re-use. See rights and permissions. Published by BMJ.

To cite: Mittal S, Madan K, Mohan A, et al. BMJ Case Rep 2019;12:e231377. doi:10.1136/bcr-2019231377

\section{DESCRIPTION}

A 37-year-old female patient presented to the pulmonary medicine outpatient services with a complaint of recurrent haemoptysis for the last 2 years. The frequency of haemoptysis was about two to three times per month, and it was $5-10 \mathrm{~mL}$ in the amount in each episode. There was no history of associated cough, shortness of breath, fever, anorexia or weight loss. She was a life-long non-smoker and had no previous history of tuberculosis. She was diagnosed to have systemic sclerosis 3 years back when she had presented with skin thickening and Raynaud's phenomenon. She was treated with low-dose steroids and nifedipine for Raynaud's phenomenon. In view of recurrent haemoptysis, she had undergone a CT scan of thorax 3 months back which had demonstrated changes suggestive of early non-specific interstitial pneumonia. A flexible bronchoscopy (FB) was also done which was reported as normal. On examination, she had skin thickening, sclerodactyly and digital pitting scars. She had multiple cutaneous telangiectasias involving, face, hands and palms (figure 1A). The chest radiograph demonstrated bilateral clear lung fields. In view of the unclear source of haemoptysis, a diagnostic FB was performed which revealed multiple mucosal telangiectasias in the entire tracheobronchial tree (figure 1B,D). Narrowband imaging (NBI) was also performed during FB which confirmed the presence of telangiectasias (figure 1C,E). The rest of the bronchoscopic examination was unremarkable. No other source of haemoptysis could be found on CT thorax as well as bronchoscopic examination, and it was attributed to endobronchial telangiectasias. In view of the diffuse nature of lesions, no therapeutic procedure was done at present. The patient is currently under follow-up with a plan for therapeutic argon plasma coagulation (APC) application in case of recurrence of haemoptysis.

Haemoptysis is a common symptom encountered in clinical practice. Its causes include infections such as tuberculosis, postinfective fibrobronchiectasis, benign or malignant endobronchial tumours, arteriovenous malformations,

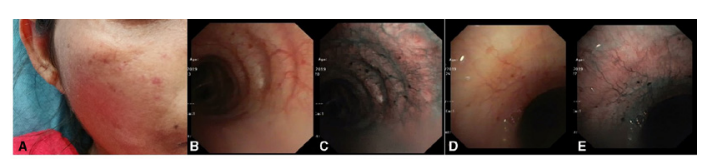

Figure 1 (A) Clinical photograph showing telangiectasias over face. Multiple pinhead size telangiectasias are seen in the left main bronchus (B) and trachea (D) which were highlighted by the use of narrow band imaging ( $C$ and $\mathrm{E})$.

\section{Patient's perspective}

I am thankful that the reason for bleeding from my mouth has now become clear. I understand the implications of no treatment at present but I would like to continue to be under regular follow-up for my bleeding.

\section{Learning points}

- Endobronchial telangiectasia should be considered as a cause of haemoptysis if no cause is apparent on initial investigations.

- A careful bronchoscopy should be performed in patients with haemoptysis to look for any endobronchial vascular lesions.

- Argon plasma coagulation is an effective therapy for endobronchial telangiectasias.

and endobronchial telangiectasias. Haemoptysis occurring in a patient with systemic sclerosis may be due to infections, pulmonary fibrosis, development of malignancy or endobronchial vascular lesions. Endobronchial telangiectasias as a cause of haemoptysis have been described in systemic sclerosis as well as in hereditary haemorrhagic telangiectasia. ${ }^{1}$ Endobronchial vascular lesions can also occur in patients with liver cirrhosis or sometimes may be idiopathic. Two most important investigations in evaluation of haemoptysis include CT scan of the thorax and a flexible bronchoscopy to look for sight of bleeding and any endobronchial lesion. Use of NBI may help in identifying superficial vascular abnormalities during $\mathrm{FB}^{2}$ Endobronchial telangiectasias can lead to haemoptysis which may be massive on occasions. The diagnosis of an endobronchial vascular lesion may be missed by a casual examination by an inexperienced operator during FB, and these patients may undergo multiple diagnostic procedures before the diagnosis is established. The treatment options include coagulation of the lesion or angioembolisation in case of large lesions if a feeding vessel is identified. Surgical resection is reserved for larger lesions not amenable to endovascular or bronchoscopic modalities. For superficial telangiectasias, electrocoagulation or APC remain important therapeutic modalities. As compared with electrocoagulation, APC has a lower risk of perforation or cartilage damage and better control of depth. ${ }^{3}$

This case highlights the importance of performing a careful bronchoscopic examination to identify mucosal vascular abnormalities in patients with haemoptysis. 
Contributors SM and TKB drafted the manuscript. KM and AM revised the manuscript.

Funding The authors have not declared a specific grant for this research from any funding agency in the public, commercial or not-for-profit sectors.

Competing interests None declared.

Patient consent for publication Obtained.

Provenance and peer review Not commissioned; externally peer reviewed.

\section{REFERENCES}

$1 \mathrm{Kim} \mathrm{JH}$, Follett JV, Rice JR, et al. Endobronchial telangiectasias and hemoptysis in scleroderma. Am J Med 1988:84:173-4.

2 Zhang J, Wu J, Yang Y, et al. White light, autofluorescence and narrow-band imaging bronchoscopy for diagnosing airway pre-cancerous and early cancer lesions: a systematic review and meta-analysis. J Thorac Dis 2016;8:3205-16.

3 Madan K, Dhungana A, Hadda V, et al. Flexible bronchoscopic argon plasma coagulation for management of massive hemoptysis in bronchial Dieulafoy's disease. Lung India 2017;34:99-101.

Copyright 2019 BMJ Publishing Group. All rights reserved. For permission to reuse any of this content visit

https://www.bmj.com/company/products-services/rights-and-licensing/permissions/

BMJ Case Report Fellows may re-use this article for personal use and teaching without any further permission.

Become a Fellow of BMJ Case Reports today and you can:

- Submit as many cases as you like

Enjoy fast sympathetic peer review and rapid publication of accepted articles

- Access all the published articles

- Re-use any of the published material for personal use and teaching without further permission

Customer Service

If you have any further queries about your subscription, please contact our customer services team on +44 (0) 2071111105 or via email at support@bmj.com.

Visit casereports.bmj.com for more articles like this and to become a Fellow 